\title{
A Novel Mutation of Thyroid Hormone Receptor Beta (I431V) Impairs Corepressor Release, and Induces Thyroid Hormone Resistance Syndrome
}

clinical case report

\author{
Monalisa FerReira Azevedo \\ GustaVo BarCELOS BarRa \\ LIGIANE DaNTAS DE MEDEIROS \\ LUIz ALBerto SIMEONI \\ LUCIANA ANSANELI NAVES \\ Francisco de A. Rocha NeVES
}

Laboratory of Molecular Pharmacology, Faculty of Health Sciences, University of Brasilia (UnB) (MFA, GBB, LDM, LAS, FARN); Sabin Institute and Laboratory of Clinical Analysis (GBB); Section of Endocrinology, -UnB (MFA, LAN); Brasilia, DF, Brazil.

\begin{abstract}
Resistance to thyroid hormone (RTH) is a rare disorder characterized by variable tissue hyporesponsiveness to thyroid hormone, usually caused by mutations in the thyroid hormone receptor beta (TR $\beta)$. We describe a large Brazilian family harboring a novel mutation affecting TR $\beta$ gene and inducing RTH. A 14-year-old girl was found to have elevated free $T_{4}$ and free $T_{3}$ plasma concentrations in coexistence with unsuppressed TSH and a questionable goiter. The diagnosis of RTH was verified by identification of a novel mutation (I431V) in the TR $\beta$ gene. Sixteen asymptomatic relatives of the proposita are also affected by the mutation. Functional studies showed that $1431 \mathrm{~V} \mathrm{mu-}$ tation exerts dominant-negative effect on wild type TR $\beta$, mainly by impairment of ligand-dependent release of corepressor SMRT. The presence of this mutation reduces potency, but does not affect efficacy of thyroid hormone action, in accordance with the clinical picture of eumetabolism of the affected individuals. (Arq Bras Endocrinol Metab 2008; 52/8:1304-1312)
\end{abstract}

Keywords: Thyroid hormone resistance; Thyroid hormone receptor; Coregulator; Mutation

\section{RESUMO}

Uma Nova Mutação no TR beta (I431V) Prejudica a Liberação de Correpressores e Induz Síndrome de Resistência ao Hormônio Tireoideano

A resistência ao hormônio tireoideano (RHT) é uma doença rara, causada por variável hiporresponsividade dos tecidos aos hormônios tireoideanos, usualmente causada por mutações no receptor beta do hormônio tireoideano (TR $\beta$ ). Descrevemos uma grande família brasileira portadora de uma nova mutação afetando o gene do TR $\beta$, induzindo RHT. Uma paciente de 14 anos de idade apresentou concentrações plasmáticas elevadas de $T_{4}$ e $T_{3}$ livres, associadas a TSH não-suprimido e bócio questionável. O diagnóstico de RHT foi estabelecido pela identificação da mutação I431V no gene do TR $\beta$. Dezesseis parentes assintomáticos da probanda também são afetados pela mutação. Estudos funcionais mostram que a mutação $1431 \mathrm{~V}$ exerce efeito dominante negativo sobre o TR selvagem, basicamente, por prejudicar a liberação do correpressor SMRT ligante-dependente. A presença desta mutação reduz a potência, mas não afeta a eficácia da ação do hormônio tireoideano, o que está de acordo com a apresentação clínica de eumetabolismo dos indivíduos afetados. (Arq Bras Endocrinol Metab 2008; 52/8:1304-1312)

Descritores: Síndrome de resistência ao hormônio tireoideano; Receptor do hormônio tireoideano; Corregulador; Mutação

\section{INTRODUCTION}

Received in $28 / 8 / 2008$

Accepetd in 14/10/2008 hyroid hormone resistance (RTH) is a rare autosomal dominant disorder, characterized by reduced target tissues responsiveness to thyroid hor- 
mones (1). Since Refetoff and cols. initially described this syndrome in 1967 (2), over 1,000 cases have been identified (3).

The hallmarks of the disorder are high levels of free thyroxine $\left(\mathrm{FT}_{4}\right)$ in serum, and elevated or inappropriate elevated levels of thyroid-stimulating hormone (TSH). Clinical phenotype is heterogeneous, varying between different families and also among affected members of the same family. Characteristically, there is a paucity of specific clinical manifestations. When present, the most common clinical findings are goiter, learning disabilities with or without hyperactive behavior, developmental delay, and sinus tachycardia. Symptoms of hypo and hyperthyroidism may coexist in the same patient, suggesting variable degrees of resistance in different tissues $(4,5)$.

Thyroid hormone receptors (TRs) are ligand-dependent transcription factors, which mediate the biological activities of $\mathrm{T}_{3}$. TRs exist in two isoforms that are encoded for by the THRA and THRB genes, which are located on chromosomes 3 and 17, respectively. The distribution of TRs $\alpha$ and $\beta$ in the diverse organs is heterogeneous, although thyroid hormone has the same affinity for both isoforms (6).

TRs modulate gene expression by binding specific DNA sequences, known as thyroid response elements (TREs), found in the promoters of TR-regulated genes. TREs are composed of repeats of the consensus halfsite AGGTCA in a variety of different orientations, including direct repeats spaced by four nucleotides (DR4), inverted palindromes (F2) and palindromes (TREpal) (7). TR activities are primarily controlled by the presence of ligand. Unliganded TRs recruit corepressor proteins such as N-CoR and SMRT, which, in turn, form part of a large corepressor complex that represses transcription of nearby genes $(8,9)$. Hormone binding induces conformation changes in TR that cause corepressor release and subsequent recruitment of coactivators such as GRIPI and SRC-1 and the TRAP/ DRIP complex $(8,9)$. TR activities are, however, also influenced by choice of oligomeric state. TRs preferentially form heterodimers with retinoid $\mathrm{X}$ receptors (RXRs), but also function as homodimers or monomers $(7,8)$.

The molecular basis of RTH in approximately $85 \%$ of subjects is heterozygous mutations of the thyroid hormone receptor (TR) $\beta$ gene, resulting in impaired triiodothyronine $\left(\mathrm{T}_{3}\right)$ binding and/or transactivation function. The severity of resistance depends on the de- gree of impaired ligand binding and/or interaction with tissue-specific nuclear cofactors $(10,11)$. Characterization of families and sporadic cases with RTH has shown that all the mutations are located in the ligand binding domain of TR $\beta 1$ and thus far, no mutations have been identified in the DBD or $\mathrm{N}$-terminal region of TR $\beta 1$ (9). Moreover, no germline mutations in TR $\alpha 1$ have been described in humans (6). Interestingly, in addition to being non-functional, the RTH mutants inhibit the action of their wild type counterparts. This dominant-negative effect by the mutant receptors may explain the dominant mode of inheritance as well as resistance to hormone action (8-9).

In this study, we describe the clinical findings and laboratory data from three generations of a large family harboring a novel TR $\beta$ mutation (I431V), and evaluate the functional profile of this mutant TR $\beta$ through in vitro and cell culture studies. Our data suggest that the mutant I431V TR $\beta$ impairs corepressor release, leading to a clinical picture of RTH.

\section{SUBJECTS AND METHODS}

\section{Case Report}

The proposita, a 14-year-old Brazilian girl, came to medical attention due to goiter. She had no other complaints and had normal neurological and psychological development. On physical examination, she had normal stature, normal heart rate, and no neurological or other abnormalities. Serum TSH was $1,92 \mu \mathrm{UI} / \mathrm{L}$ (normal range, $0,3-5,0)$, free $\mathrm{T}_{4}\left(\mathrm{FT}_{4}\right)$ was $2,31 \mathrm{ng} / \mathrm{dL}$ (normal range, $0,75-1,8)$, and free $\mathrm{T}_{3}\left(\mathrm{FT}_{3}\right)$ was 0,78 $\mathrm{ng} / \mathrm{dL}$ (normal range, $0,3-0,5 \mathrm{l}$ ), on repeated occasions. Thyroid peroxidase antibody was negative, and thyroid ultrasonography was normal. Blood samples were obtained from all family members, all of them asymptomatic for thyroid diseases. Informed consents were obtained for this study approved by the Ethics Committee from the University of Brasilia.

\section{Mesurements of hormones in serum}

$\mathrm{FT}_{4}, \mathrm{FT}_{3}$ and $\mathrm{TSH}$ were measured by chemiluminescence assay, using Kit ADVIA CENTAUR (Centaur, Siemens).

\section{TR $\beta$ sequencing}

Genomic DNA of the proposita and her family members was extracted from $50 \mu$ l whole blood by the Chel- 
ex-100 method (12), and exons 9 and 10 of the TR $\beta$ were gene amplified through PCR, using the sense and antisense oligonucleotide primers described by Adams and cols. (13). The products of amplification were sequenced directly using the automated sequencing ABI377 (Perkin-Elmer Corp., Foster City, CA, USA)

To examine the family members we used PCR based restriction fragment length polymorphism (RFLP) analysis since the sequence variant identified here introduces a new BccI (Fermentas Inc., Hanover, $\mathrm{MD}, \mathrm{USA}$ ) recognition site in exon 10 .

\section{Plasmids}

To perform functional studies, we used the following plasmids: $\mathrm{T}_{3}$-inducible reporters containing two copies of each TRE driving luciferase expression, mammalian (pCMX) expression vectors for TR and RXR (14), GST fusion expression vectors (pGEX) for SMRT (15), SRC-1 (16) and RXR (14).

New TR mutants reported in our studies (pCMXTR $\beta I 431 \mathrm{~V}$ and pGEX-TRI43IV) were created in existing vectors using QuikChange site-directed mutagenesis kits (Stratagene).The construct was checked for correct DNA insertion and presence of mutation by automated DNA sequencing ABI-377 (Perkin-Elmer Corp., Foster City, CA, USA).

\section{Mammalian Cell Culture, Electroporation, and Luciferase Assays}

Human promonocyte U937 cells were maintained at $37^{\circ} \mathrm{C}, 5 \% \mathrm{CO}_{2}$, subcultured in RPMI 1640 media with $10 \%$ newborn bovine serum, $2 \mathrm{mM}$ glutamine, 50 units/ $\mathrm{ml}$ penicillin, and $50 \mathrm{~g} / \mathrm{ml}$ streptomycin. Transfections were carried out as described previously (17). After incubation for $24 \mathrm{~h}$ at $37^{\circ} \mathrm{C}$ with ethanol or $\mathrm{T}_{3}$, cells were collected by centrifugation, and pellets were solubilized by addition of $150 \mu \mathrm{l}$ of $0.25 \mathrm{M}$ Tris- $\mathrm{HCl}, \mathrm{pH} 7.6$, containing $0.1 \%$ Triton $\mathrm{X}-100$. Luciferase activity was analyzed by standard methods (luciferase assay system, Promega). Experiments were performed in triplicate and expressed as fold induction \pm SEM.

\section{Glutathione S-Transferase Pull-Down Assays}

pCMX-TR $\beta 1 w t$ or pCMX-TRI43IV vectors were used to produce radiolabeled full-length receptor in vitro, using the TNT-Coupled Reticulocyte Lysate System (Promega) and $\left[{ }^{35} \mathrm{~S}\right]$ methionine. GST SRCla (381-
882), GST-RXR (full-length), and GST-SMRT (9871491) fusion proteins were prepared using conventional protocols (Pfizer, New York, NY). In brief, the plasmids were transformed into BL21, cultured into $2 x L B$ medium, pelleted and resuspended in lxTST buffer $(50 \mathrm{mM}$ Tris $\mathrm{pH} 7.5,150 \mathrm{mM} \mathrm{NaCl}$, and $0.05 \%$ Tween 20 ) with $1 \mathrm{mM}$ DTT, $0.5 \mathrm{mM}$ phenylmethylsulfonyl fluoride, and protease inhibitor cocktail 1:1000 (Sigma, St. Louis, MO). Then, the solution was incubated with lysozyme and sonicated (three 2.5-min cycles, amplitude $70 \%, 1$ pulse/s with a break of 5 min between each cycle). The debris were pelleted and the supernatant was incubated for $2 \mathrm{~h}$ with $500 \mu \mathrm{l}$ of glutathione-Sepharose $4 \mathrm{~B}$ beads equilibrated with $1 \mathrm{x}$ TST. GST fusion protein beads were washed with $1 \mathrm{x}$ TST containing $0.05 \%$ Nonidet P-40 and resuspended in 1x TST with $1 \mathrm{mM}$ DTT, $0.5 \mathrm{mM}$ phenylmethylsulfonyl fluoride, protease inhibitor cocktail 1:1000 (Sigma), and 50\% glycerol, and then stored at minus $20^{\circ} \mathrm{C}$. All procedures above were carried out at $4^{\circ} \mathrm{C}$. For the binding assay, the glutathione bead suspension containing $4 \mu \mathrm{g}$ of GST fusion protein was incubated with $3 \mu \mathrm{l}$ of ${ }^{35} \mathrm{~S}$-labeled protein in $150 \mu \mathrm{l}$ of $1 \mathrm{x}$ TST buffer with $0.1 \%$ Noni$\operatorname{det}$ P-40, $0.1 \%$ Triton X-100, $1 \mathrm{mM}$ DTT, and $2 \mathrm{~g} / \mathrm{ml}$ bovine serum albumin, in the presence of $10^{-6} \mathrm{M} \mathrm{T}_{3}$ or vehicle. After a $2 \mathrm{~h}$ incubation at $4^{\circ} \mathrm{C}$, the beads were washed with the same incubation buffer. The beads with associated proteins were analyzed on 10\% SDSpolyacrylamide gels and visualized by autoradiography.

\section{T3 Binding Assay}

TRs were expressed using the TNT T7 quick coupled transcription translation system (Promega). The affinities of $T_{3}$ binding were determined using a saturation binding assay. $15 \mathrm{fmol}$ of each in vitro translated protein were incubated overnight at $4{ }^{\circ} \mathrm{C}$ with varying concentrations of $\left[{ }^{125} \mathrm{I}\right] \mathrm{T}_{3}$ (PerkinElmer Life Sciences) in $100 \mu \mathrm{l}$ of E400 buffer $\left(400 \mathrm{mM} \mathrm{NaCl}, 20 \mathrm{mM} \mathrm{KPO}_{4}\right.$, $\mathrm{pH} 8,0.5 \mathrm{mM}$ EDTA, $1.0 \mathrm{mM} \mathrm{MgCl}, 10 \%$ glycerol), $1 \mathrm{mM}$ monothioglycerol, and $50 \mu \mathrm{g}$ of calf thymus histones (Calbiochem). The bound $\left[{ }^{125} \mathrm{I}\right] \mathrm{T}_{3}$ was isolated by gravity flow through a $2 \mathrm{ml}$ Sephadex G-25 (Amersham Biosciences) column and quantified using a gamma-counter (Cobra II - PACKARD, Austrália). Binding curves were fit by nonlinear regression, and equilibrium dissociation constant $(\mathrm{Kd})$ values were calculated using the one-site saturation binding model, contained in the Prism version 4.00 program (GraphPad Software, Inc., San Diego, CA). 


\section{Statistics}

Student's t-test or one-way analysis of variance followed by Student-Newman-Keuls multiple comparison test was employed for assessment of significance (Prism version 4.0; GraphPad Software Inc., San Diego, CA). Differences were considered to be significant at $\mathrm{p}<0.05$.

\section{RESULTS}

\section{A novel mutation was found in the $\operatorname{TR} \beta$ of the proposita and her family}

Sequencing of PCR products in both directions revealed an heterozygous missense mutation $(A \rightarrow G)$ in exon 10 of the TR $\beta$ gene, which resulted in replacement of a normal isoleucine for a valine at codon 431 (I431V).

Investigation of family members, by PCR based restriction fragment length polymorphism (RFLP) analysis, showed other 16 heterozygous individuals (Figure 1). Affected members are distributed through three generations, and none of them presented any thyroid related symptom or have had previously suspected RHT diagnosis.

Once the proposita showed only minimal phenotype alterations, characterized by normal physical examination, including absence of goiter and tachycardia, and mild elevation on $\mathrm{FT}_{3}$ and $\mathrm{FT}_{4}$ levels with unsuppressed TSH levels, we decided to investigate all of the affected family members. Among these 16 individuals, all but three had serum thyroid hormone levels similar to those found in the proposita (Figure 2). One affected patient's aunt had elevated TSH level $(5 \mathrm{lmUI} / \mathrm{L})$ with low-normal $\mathrm{FT}_{4}$, reduced $\mathrm{FT}_{3}$ and a positive test for thyroperoxidase autoantibodies, configurating concomitant primary hypothyroidism, not previously suspected (data not shown). Other two affected members presented normal hormonal dosages (Figure 2). Moreover, all of them were completely asymptomatic, including the hypothyroid patient.

\section{I431V reduces sensitivity, but does not affect efficacy of thyroid hormone action}

The transcriptional properties of the I431V mutant were examined by transfection assays, using either the mutant or wild type TR $\beta 1$ isoform together with a reporter gene containing positively regulated thyroid hormone receptor response elements (TREs), in eukaryotes U937 cells. At lower $\mathrm{T}_{3}$ concentrations, transient transfection studies with a reporter gene containing DR4, F2 and TREpal responsive element showed decreased transcriptional activation induced by TR $\beta$ I431V. Otherwise, utilizing higher amounts of $T_{3}$, this defect has been overcome. Therefore, at $100 \mathrm{nM}$ and 1 $\mu \mathrm{M} \mathrm{T}_{3}$ concentrations, TR $\beta$ I43IV transcriptional activity was fully, and achieved the greater maximal response comparable to wt TR $\beta 1$ (Figure $3 \mathrm{~A}, \mathrm{~B}$ and $\mathrm{C}$ ). EC50 values obtained at DR4 responsive element were 33 fold greater for TR $\beta$ I $431 \mathrm{~V}$, compared to wt TR $\beta$ (EC50 for wt TR $\beta$ 9,91 x 10-9 M; EC50 for TR $\beta$ I431V

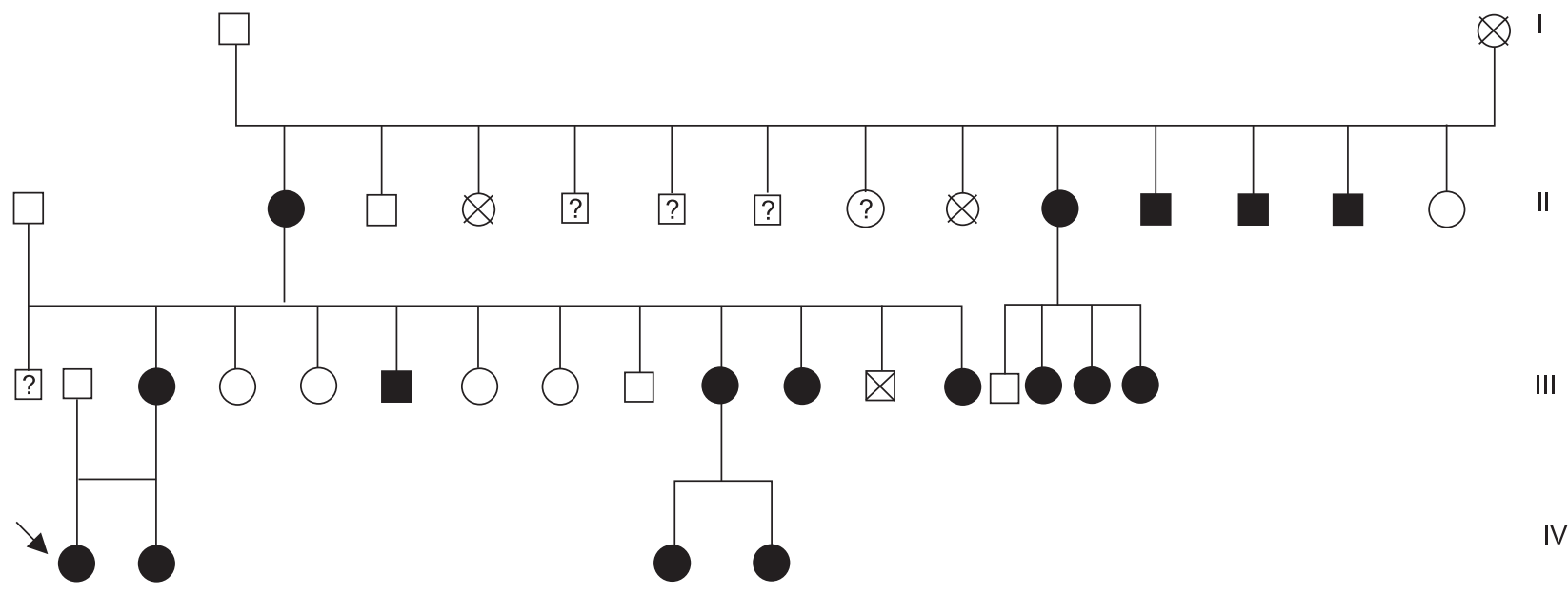

Figure 1. Pedigree of a family with thyroid hormone resistance. Consanguinity was ruled out. Closed symbols represent affected members; open symbols, unaffected members. The arrow indicates the proposita. Subjects marked with (?) declined genetic analysis. 
$\mathrm{TSH} \mathrm{mUl} / \mathrm{I}$

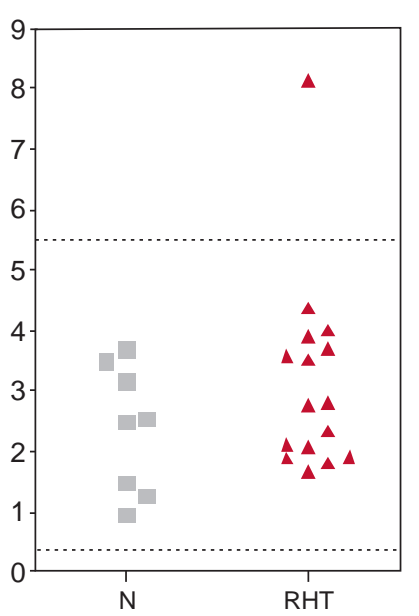

FT4 ng/dl

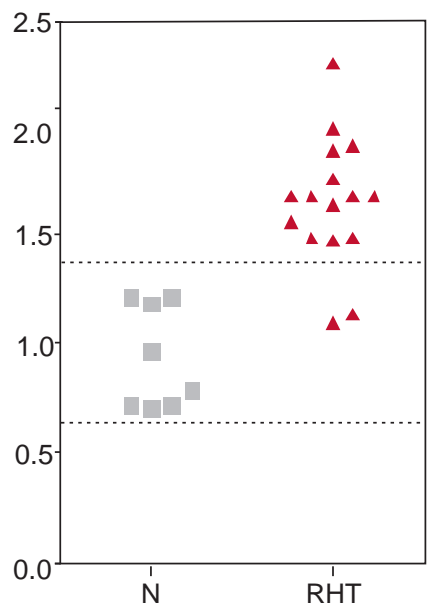

FT3 $\mathrm{pg} / \mathrm{ml}$

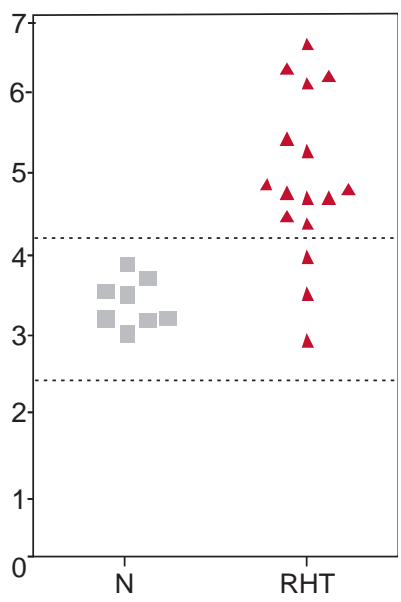

Figure 2. Hormone values in a family with thyroid hormone resistance syndrome (RHT). N = unaffected first grade family members to persons with RHT. Dotted lines show normal ranges.

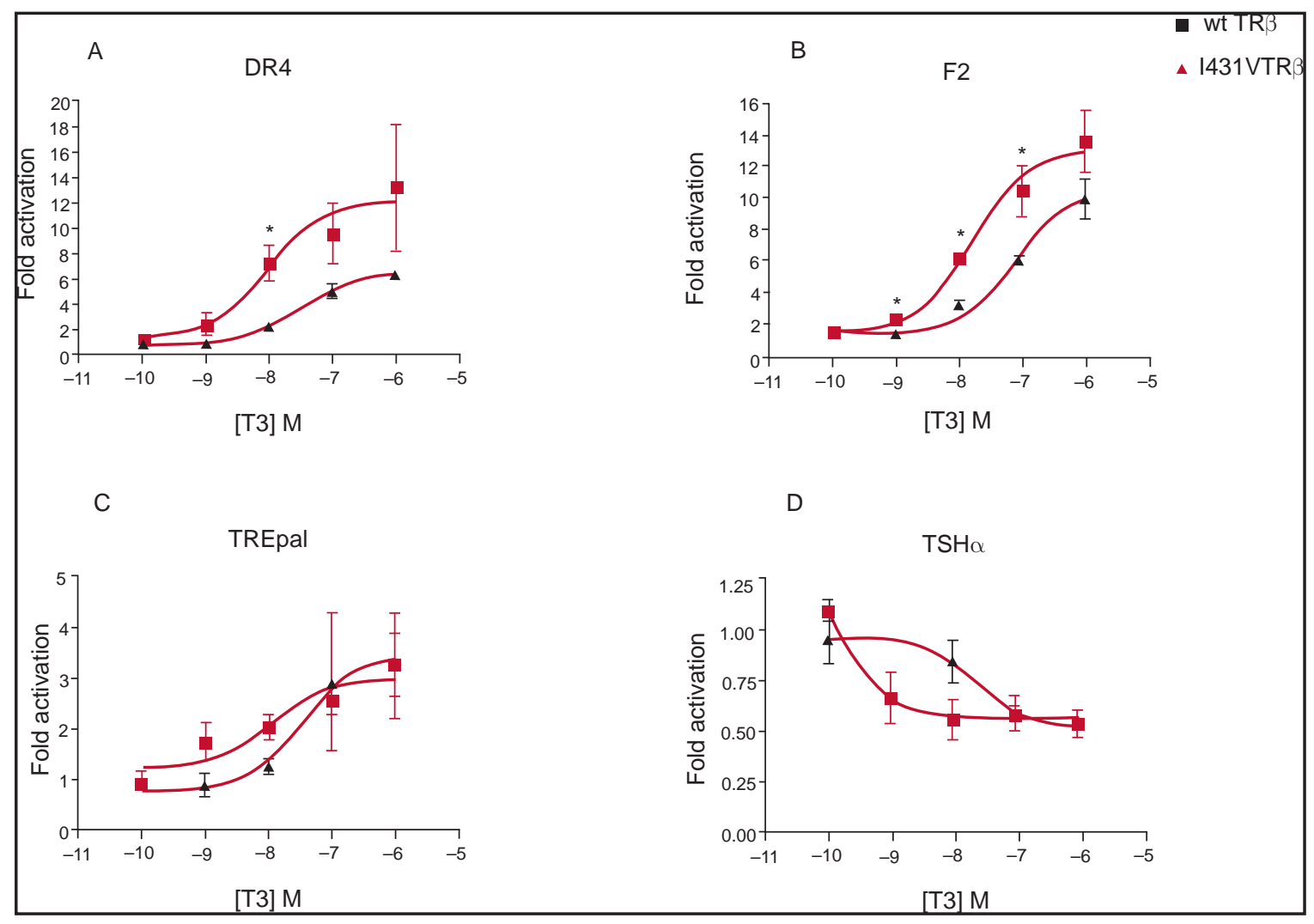

Figure 3. Transcriptional effects of increasing doses of $T_{3}$ at DR4, F2, TREpal and TSH responsive elements. U937 cells were cotransfected with I431V TR $\beta(\boldsymbol{\Delta})$ or wt TR $\beta(\boldsymbol{\nabla})$, and with firefly luciferase reporter gene driven by a promoter containing the various responsive elements sequence. The activation value for each $\mathrm{T}_{3}$ concentration is the mean of triplicate determinations. 
$\left.3,01 \times 10^{-8} \mathrm{M}\right)$. Similar results were observed at F2 responsive element, where EC50 for TR $\beta$ I $431 \mathrm{~V}$ was 5 fold greater than for wt TR $\beta$ (EC50 for wt TR $\beta$ 1,63 x $10^{-8} \mathrm{M}$ vs $8,17 \times 10^{-8} \mathrm{M}$ for I431V TR $\beta$ ), and at TREpal, where it was 3 fold greater for TR $\beta$ I43IV (EC50 $1,06 \times 10^{-8}$ for wt TR $\beta$ vs $3,26 \times 10^{-8}$ for I431V TR $\beta$ ).

We examined next the mutant transcriptional properties with the negatively regulated target gene promoter, i.e. the human pituitary TSH $\alpha$ subunit. At TSH promoter, TR $\beta$ I $431 \mathrm{~V}$ showed a reduced capacity to repress transcription at lower $\mathrm{T}_{3}$ concentrations ( $\operatorname{lnM}$ and $10 \mathrm{nM})$, but not at higher concentrations of 100 $\mathrm{nM}$ and $\mathrm{l} \mu \mathrm{M}$. Therefore, the dose-response curve is also slightly shifted to the left, as shown in Figure 3D. Collectively, these results showed that I43IV TR $\beta$ has impaired sensitivity, keeping the maximum response (efficacy) similar to wt TR $\beta 1$.

\section{I431V exerts dominant-negative effect on TR $\beta$}

Having established the functional capabilities of I43IV $\mathrm{TR} \beta$, the ability of this mutant to modulate the activity of wt TR $\beta 1$ (dominant negative effect) was examined. Wild type $\beta$ receptor was co-transfected with equal concentrations of I431V. Under these conditions, I431V markedly inhibited both positive (DR4) and negative (TSH) transcriptional responses mediated by the wild type receptor (Figure 4).
A

SRC-1

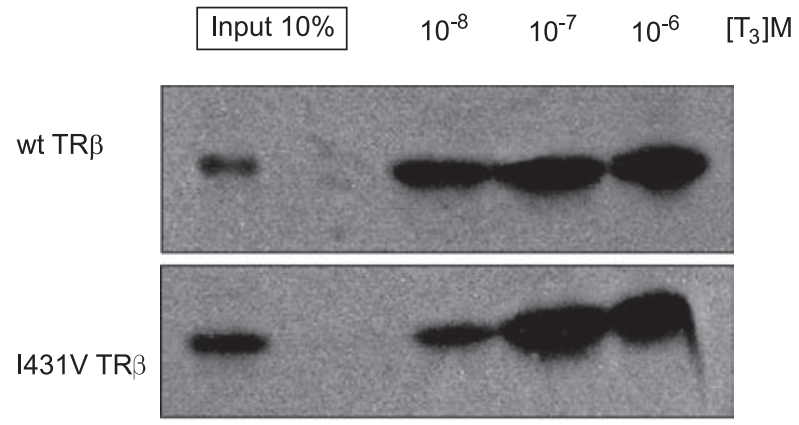

B SMRT

I431V TR3

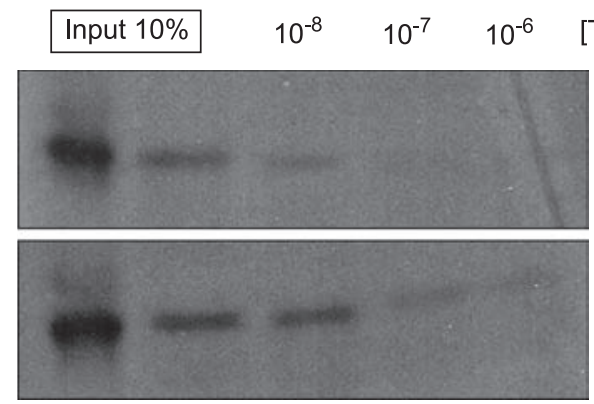

Figure 5. Autoradiograms of SDS-polyacrylamide gels used to separate labeled TRs bound to SRC-1 in pull-down assay, using different concentrations of $\mathrm{T}_{3}$. $\mathrm{A}$ : SRC-1 recruitment by $1431 \mathrm{~V}$ TR $\beta$ is impaired at low concentrations of $\mathrm{T}_{3}$. B: TR $\beta$ I431V retains the corepressor SMRT stronger than does TR $\beta$ w†

\section{A}

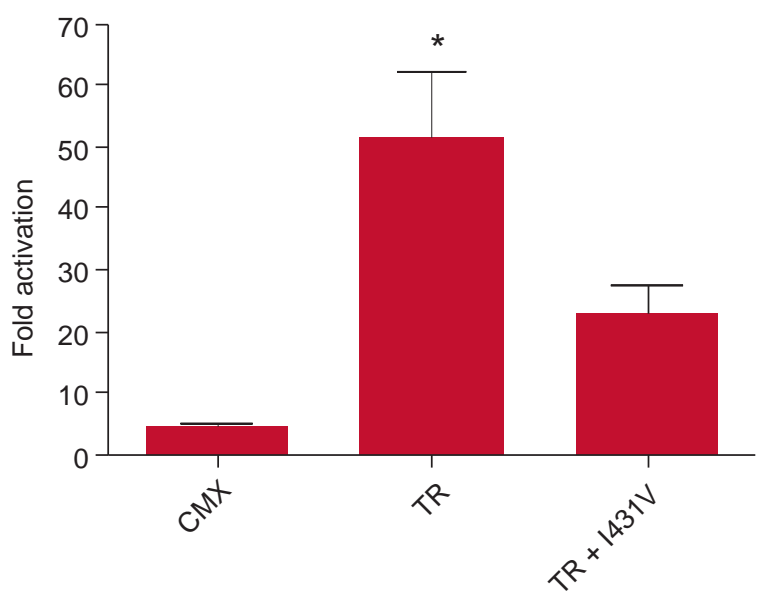

B

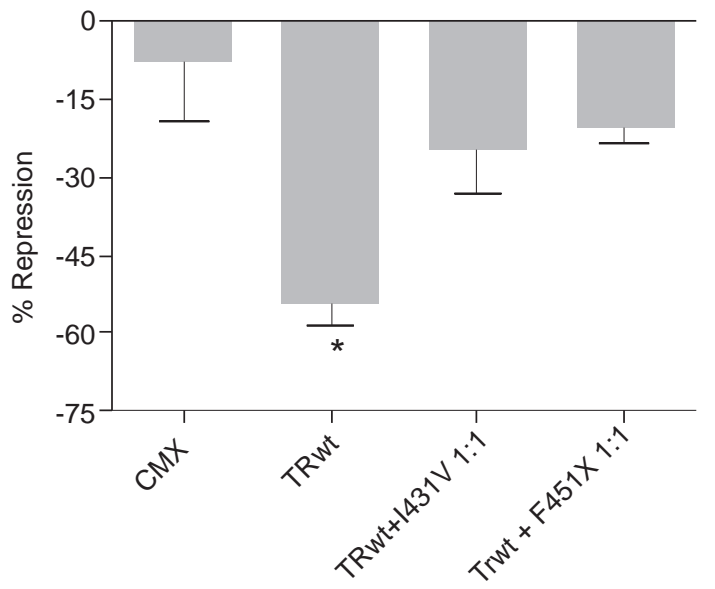

Figure 4. Dominant negative effect of I431V TR $\beta$. U937 cells were treated with 100nmol/liter of $T_{3}$. A: fold activation at DR4 responsive element. B: \% of repression at TSH responsive element. 


\section{I431V demonstrate impaired ligand- dependent release of SMRT}

To further characterize whether the I431V mutant retained the ability to interact with nuclear co-factors, we performed GST pull down assay. Figure 5A shows that $\operatorname{TR} \beta$ I $431 \mathrm{~V}$ recruitment of the coactivator SRC-1 is slightly reduced, compared to TR $\beta$ wt. However, it is noteworthy that I43IV TR $\beta$ retains the corepressor SMRT stronger than does wt TR $\beta$, even at higher $\mathrm{T}_{3}$ concentrations, such as $100 \mathrm{nM}$ and $1 \mu \mathrm{M}$ (Figure $5 \mathrm{~B}$ ). On the contrary, I43IV TR $\beta$ heterodimerization with RXR was similar to wt TR $\beta$ (Figure 6).

\section{$1431 \mathrm{~V}$ binding affinity is reduced}

$\mathrm{T}_{3}$ binding assay was performed to address thyroid hormone binding affinity of TR $\beta$ I43IV. Our results showed that TR $\beta$ I $431 \mathrm{~V}$ affinity for $\mathrm{T}_{3}$ was 2.6 times lower than TR $\beta$ wt (Kd for TR $\beta$ wt $0,188 \mathrm{nM}$ vs $0,49 \mathrm{nM}$ for I431V).

\section{DISCUSSION}

RHT is an inherited condition induced by defects that reduce the responsiveness of the target tissues to thyroid hormone ( 1 ). The precise incidence is unknown, but it is estimated to be 1 case per 40,000 live births (18). In the untreated patient, elevation of serum free $\mathrm{T}_{4}$ is a sine qua non requirement for the diagnosis of the syndrome $(3,4)$.

Likewise, RHT diagnosis must be suspected in every patient that presents persistent elevation of circulating free $\mathrm{T}_{4}$ and free $\mathrm{T}_{3}$, in association with nonsupressed serum TSH, and in the absence of intercurrent illness, drugs, or alteration of thyroid hormone transport serum

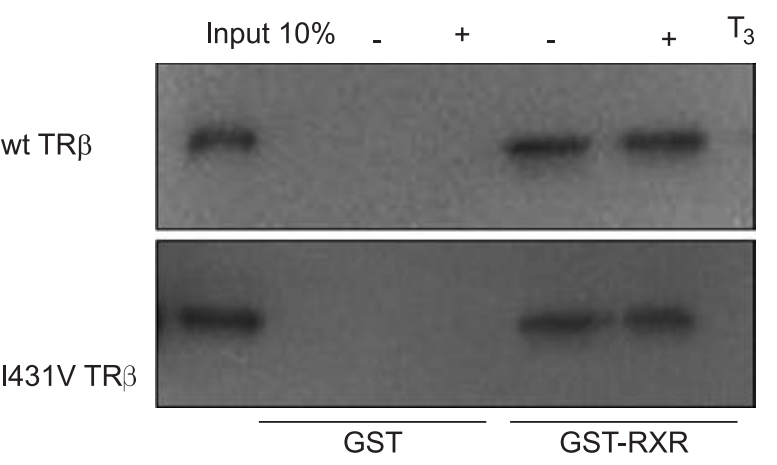

Figure 6. Autoradiograms of GST pull-down assay, showing normal heterodimerization of I431V TR $\beta$ with RXR. proteins. Differential diagnosis must concern autonomous hypersecretion of TSH associated with pituitary adenomas. The tumors may be demonstrated by magnetic resonance imaging of the pituitary gland, or this diagnosis may be made by elevation of circulating $\alpha$-subunit, or by failure of serum TSH to increase above the basal level in response to TRH (3).

Here, we describe an asymptomatic female patient that presented characteristic thyroid hormone levels alterations that narrowed the possibility of RHT. TSH hypersecretion was discharged by pituitary imaging that was normal.

The THRB gene consists of 10 exons (19); the aforementioned mutations are located in the last $4 \mathrm{ex}-$ ons, which code for the hinge region and, more frequently, the ligand-binding domain of the receptor, at the carboxyl-terminus of the TR $\beta$. The majority of these mutations result in a reduction in $\mathrm{T}_{3}$-binding and/or an impairment in transactivation (20). There have been described at least 122 mutations affecting THRB gene, including deletions, insertions, and much more frequently, point mutations (21-23). The largest family reported in the literature until now is composed by 36 persons harboring a missense mutation at THRB gene (24).

The mutation identified in this family results in an alteration in codon 431 in helix 11 (HIl) of the ligand-binding domain of TR $\beta$, a residue oriented towards the interior of receptor's structure. Mutations affecting this region, at codon 429 , normally presents itself as a predominantly pituitary pattern of RHT in humans $(10,25,26)$. Another mutation, also localized at codon 431 but resulting in a different amino acid substitution, I431T, has been previously described as causing predominantly pituitary RHT, concerning clinical presentation and TSH, $\mathrm{T}_{3}$ and $\mathrm{T}_{4}$ levels in serum obtained from the affected patient (9). Afterwards, in another study using reporter gene assays with positive and negative response elements, Safer et al. demonstrated that I431T mutation causes generalized resistance to thyroid hormone (27).

In our study, I431V TR $\beta$ also showed a dominant negative effect upon positive (DR4) and negative (TSH promoter) regulated genes, behaving biochemically as a generalized resistance to thyroid hormone. In spite of the fact that I431T TR $\beta$ mutant showed a moderate reduction of $\mathrm{T}_{3}$ binding affinity, I431V mutant displayed a slightly impairment in affinity. This difference can be explained by the fact that both valine and isoleucine have a 
hydrophobic side group. Consonant with these findings, at higher $\mathrm{T}_{3}$ concentrations, the mutant I431V TR $\beta$ recovered coactivator (SRC-1) recruitment, and retained the ability to regulate transcription.

Interestingly, in I431V mutant, $\mathrm{T}_{3}$ ligand-dependent corepressor release was markedly lower than expected from the impaired ligand-binding affinity. Even at higher $\mathrm{T}_{3}$ doses, with normal recruitment of SRC-1, I43IV still binds to SMRT. Similar results were described in other RTH mutants. Mutations at the receptor carboxyl terminus in the ligand-inducible trans-activation function (AF-2) region, such as L454S, shows similar pattern. This mutant interacts stronger with a nuclear receptor corepressor (NCoR) than does the wild-type receptor, and the $\mathrm{T}_{3}$-dependent release of NCoR is markedly impaired (28).

Other studies have shown that a number of RTH mutants interact aberrantly with corepressors. For two mutations ( $\mathrm{P} 453 \mathrm{~A}$ and $\mathrm{P} 453 \mathrm{H}$ ), involving a proline residue that precedes an amphipathic helix at the receptor carboxy terminus, ligand-dependent corepressor release was markedly reduced. Furthermore, when introduced into a RTH mutant, artificial mutations that abolished corepressor interaction abrogated the dominant negative activity of RTH mutants (29). Another mutation, $\mathrm{R} 383 \mathrm{H}$, localized in the loop between $\mathrm{H} 9$ and $\mathrm{H10}$, induces resistance to thyroid hormone and impairs corepressor release $(25,30)$. These properties are shared by another mutant (R429Q), which is located in Hll (25). Notwithstanding, R429Q is associated with greater impairment of negative than positive transcriptional function. This finding differs from the $\mathrm{I} 43 \mathrm{IV}$, since this RTH mutant impairs both positive and negative responsive genes (25).

We also showed a reduced affinity of the I431V mutant receptor for thyroid hormone. Altogether, these findings are consistent with the clinical picture of eumetabolism of the affected individuals.

Up to now, no specific treatment is available to correct the defect on RTH and patients in euthyroidism should not be treated. However, follow-up of patients with RTH has fully been recommended, once the clinical presentation may vary among individuals with the same mutation or even in the same individual throughout lifetime $(20,31)$.

In this study, we have described a large family harboring a novel mutation of TR $\beta$ gene that impairs corepressor release, and induces thyroid hormone resistance syndrome. Although the majority of the heterozygous patients presented only minimal alterations in thyroid hormone levels, two of the affected individuals showed normal hormonal dosages, which illustrate the variability of clinical presentation that occurs in RTH, even among members of the same family. Knowledge about this illness is clinically relevant, at least for family counseling, and is also very important to contribute to a better comprehension of thyroid physiology.

Acknowledgments: This work was supported by Brazilian Research Council CNPq 486388/2006-9 and Finatec (02/2006 Universidade de Brasilia). Disclosures: All the authors report no conflicts of interest.

\section{REFERENCES}

1. Refetoff $S$, Weiss RE, Usala SJ. The syndromes of resistance to thyroid hormone. Endocr Rev 1993; 14:348-400.

2. Refetoff $S$, DeWind LT, DeGroot LJ. Familial syndrome combining deaf-mutism, stippled epiphyses, goiter and abnormally high PBI: possible target organ refractoriness to thyroid hormone. JCEM 1967; 27:279-294.

3. Refetoff S. Resistance to thyroid hormone. In: Braverman LE, Utiger RE, editors. Werner and Ingbar's the thyroid: a fundamental and clinical text. 9th ed. Philadelphia: Lippincott, Williams and Wilkins; 2005.p.1109-1129.

4. Beck-Peccoz P, Chatterjee VK. The variable clinical phenotype in thyroid hormone resistance syndrome. Thyroid 1994; 4:225-32.

5. Mamanasiri S, Yesil S, Domitrescu A, Liao X-H, Demir T, Weiss RE et al. Mosaicism of a Thyroid Hormone Receptor- $\beta$ Gene Mutation in Resistance to Thyroid Hormone. JCEM 2006;91(9):3471-77.

6. Cheng SY. Thyroid hormone receptor mutations and disease: beyond thyroid hormone resistance. Trends Endocrinol Metab 2005;16:176-82.

7. Velasco LF, Togashi M, Walfish PG, Pessanha RP, Moura FN et al. Thyroid hormone response element organization dictates the composition of active receptor. J Biol Chem. 2007 282:12458-66.

8. Oetting A, Yen PM. New insights into thyroid hormone. Best Pract Res Clin Endocrinol Metab 2007;21(2):193-208.

9. Yen P M. Molecular basis of resistance to thyroid hormone. Trends Endocrinol Metab 2003; 14:327-33.

10. Wu SY, Cohen RN, Simsek E, Senses DA, Yar NE, Grasberger H et al. A Novel Thyroid Hormone Receptor- $\beta$ Mutation That Fails to Bind Nuclear Receptor Corepressor in a Patient as an Apparent Cause of Severe, Predominantly Pituitary Resistance to Thyroid Hormone. JCEM 2006;91(5):1887-95.

11. Chatterjee VK, Nagaya T, Madison LD, Datta S, Rentoumis A, Jameson JL Thyroid hormone resistance syndrome. Inhibition of normal receptor function by mutant thyroid hormone receptors. J Clin Invest 1991;87:1977-84.

12. Walsh PS MDHR. Chelex 100 as a medium for simple extraction of DNA for PCR-based typing from forensic material. Biotechniques 1991;10(4):506-513.

13. Adams $M$, Matthews $C$, Collingwood $T$, Tone $Y$, Beck-Peccoz $P$, Chatterjee KK. Genetic analysis of 29 kindreds with generali- 
zed and pituitary resistance to thyroid hormone. J Clin Invest 1994;94:506-15.

14. Ribeiro RC, Feng W, Wagner RL, Costa $\mathrm{CH}$, Pereira AC, Apriletti JW et al. Definition of the surface in the thyroid hormone receptor ligand domain for association as homodimers and heterodimers with retinoid X receptor. J. Biol. Chem 2001;276: 14987-95.

15. Webb P, Nguyen P, Kushner PJ. Differential SERM effects on corepressor binding dictate $\mathrm{ER} \alpha$ activity in vivo. J Biol Chem 2003;278:6912-20.

16. Feng W, Ribeiro RC, Wagner RL, Nguyen H, Apriletti JW, Fletterick RJ et al. Hormone-dependent coactivator binding to a hydrophobic cleft on nuclear receptors. Science 1998;280:1747-49.

17. Leitman DC, Costa CH, Graf H, Baxter JD, Ribeiro RC. Thyroid hormone activation of transcription is potentiated by activators of cAMP-dependent protein kinase. J. Biol. Chem 1996;271: 21950-55.

18. Lafranchi SH, Snyder DB, Sesser DE, Skeels MR, Singh N, Brent GA et al. Follow-up of newborns with elevated screening T4 concentrations. J Pediatr 2003;143:296-301.

19. Kim JH, Park TS, Baek HS, Kim GH, Yoo HW et al. A newly identified insertion mutation in the thyroid hormone receptor- $\beta$ gene in a Korean family with generalized thyroid hormone resistance. J Korean Med Sci 2007;22:560-3.

20. Refetoff S, Dumitrescu AM. Syndromes of reduced sensitivity to thyroid hormone: genetic defects in hormone receptors, cell transporters and deiodination. Best Pract Res Clin Endocrinol Metab 2007; 21(2):277-305.

21. Furlanetto $T$, Kopp $P$, Peccin $S, G u$ WX, Jameson JL. A novel mutation (M310L) in the thyroid hormone receptor $\beta$ causing resistance to thyroid hormone in a Brazilian kindred and a neonate. Mol Genetics Metabol 2000;71:520-6.

22. Frank-Raue K, Lorenz A, Haag C, Höppner W, Boll HU, Knorr D et al. Severe form of thyroid hormone resistance in a patient with homozygous/hemizygous mutation of T3 receptor gene. Eur J Endocrinol 2004;150:819-23.

23. Kong APS, Lam CW, Chan AOK, Yiu SF, Tiu SC. Resistance to thyroid hormone in a Chinese family with R4290 mutation in the thyroid hormone receptor beta gene. Hong Kong Med J 2005;11:125-9.

24. Kvistad PH, Lovas C, Boman H, Myking OL. Retarded bone growth in thyroid hormone resistance. A clinical study of a large family with a novel thyroid hormone receptor mutation. Eur J Endocrinol 2004;150:425-30.

25. Flynn TR, Hollenberg AN, Cohen O, Menke JB, Usala SJ, Tollin $\mathrm{S}$ et al. A novel C-terminal domain in the thyroid hormone receptor selectively mediates thyroid hormone inhibition. J Biol Chem 1994;269:32713-6.

26. Cohen RN, Putney A, Wondisford FE, Hollenberg AN. The nuclear corepressors recognize distinct nuclear receptor complexes. Mol Endocrinol 2000;14:900-14.

27. Safer JD, Langlois MF, Cohen R, Monden T, John-Hope D, Madura $\mathrm{J}$ et al. Isoform variable action among thyroid hormone receptor mutants provides insight into pituitary resistance to thyroid hormone. Mol Endocrinol 1997;11(1):16-26.

28. Tagami T, Gu WX, Peairs PT, West BL, Jameson JL. A novel natural mutation in the thyroid hormone receptor defines a dual functional domain that exchanges nuclear receptor corepressors and coactivators. Mol Endocrinol 1998;12(12): 1888-902.

29. Yoh SM, Chatterjee VK, Privalsky ML. Thyroid hormone resistance syndrome manifests as an aberrant interaction between mutant $\mathrm{T} 3$ receptors and transcriptional corepressors. Mol Endocrinol 1997;11(4):470-80.

30. Clifton-Bligh RJ, de Zegher F, Wagner TN, Collingwood IF, Francois M, Van Helvoirt R, et al. A novel TR beta mutation (R383H) in resistance to thyroid hormone syndrome predominantly impairs corepressor release and negative transcriptional regulation. Mol Endocrinol 1998;12(5):609-21.

31. Beck-Peccoz P, Persani L, Calebiro D, Bonomi M, Mannavola D, Campi I. Syndromes of hormone resistance in the hypothalamic-pituitary-thyroid axis. Best Pract Res Clinical Endocrinol Metab 2006;20(4):529-46.

\section{Correspondence to:}

Francisco de Assis Rocha Neves

Laboratório de Farmacologia Molecular, UnB

Caixa Postal 4473

70919-970 Brasília, DF

E-mail: chico@unb.br 